\title{
PENGUATAN DAN PENERAPAN PARADIGMA PROBLEM SOLVING METODE POLYA DALAM PEMBELAJARAN MATEMATIKA DI SMA NEGERI 1 PRAYA LOMBOK TENGAH
}

\section{Strengthening And Application Of The Problem-Solving Paradigm Polya Method In Mathematics Learning In Sma Negeri 1 Praya Central Of Lombok}

\author{
Syamsul bahri", Qurratul Aini, lailia Awalushaumi, Marliadi Susanto \\ Program Studi Matematika FMIPA Universitas Mataram \\ Jalan Majapahit Nomor 62, Kota Mataram, Provinsi NTB \\ *Alamat Korespondensi: syamsul.math@unram.ac.id
}

(Tanggal Submission: 5 Desember 2019, Tanggal Accepted: 30 Agustus 2020)

\begin{abstract}
ABSTRAK
Metode pembelajaran merupakan salah satu faktor yang menentukan keberhasilan dalam suatu proses pembelajaran, termasuk didalamnya pembelajaran matematika. Metode problem solving merupakan salah satu metode pembelajaran yang berbasis masalah yang dapat membuat proses pembelajaran menjadi lebih menarik dan menyenangkan. Kegiatan pengabdian ini bertujuan untuk memberikan pelatihan dan pemahaman kepada siswa tentang penerapan prosedur dan strategi problem solving model Polya dalam menyelesaikan permasalahan matematika yang berifat rutin maupun tidak rutin. Hasil kegiatan memperlihatkan bahwa siswa SMA Negeri 1 Praya Lombok Tengah belum familiar dengan metode ini, yang tercermin dalam jawaban siswa terhadap angket yang diberikan. Terhadap penerapan metode problem solving model Polya dalam penyelesaian soal matematika, jawaban siswa berbeda untuk tipe soal rutin dan yang tidak rutin. Untuk soal tipe rutin $87,50 \%$ siswa menjawab dengan benar, sedangkan untuk tipe soal yang tidak rutin 56,26 \% siswa menjawab tetapi belum maksimal memanfaatkan metode ini untuk memperoleh solusi dari permasalahan yang diberikan.

Kata kunci: pembelajaran matematika, problem solving, Polya, metode pembelajaran, sekolah menengah.

\section{PENDAHULUAN}

Sains dan teknologi telah menuntun manusia menuju peradaban yang lebih maju dan merupakan bagian yang tak terpisahkan dari kebudayaaan masyarakatnya. Pada era globalisasi sekarang ini, penguasaan sains dan teknologi merupakan indikator signifikan dalam percepatan pembangunan/pertumbuhan suatu bangsa atau daerah. Upaya mengejar ketertinggalan sains dan

teknologi oleh bangsa-bangsa yang sedang membangun terhadap bangsa-bangsa yang sudah maju bukanlah suatu hal yang mudah karena kondisinya sangat dipengaruhi oleh nilai-nilai kebudayaan masyarkat setempat. Dalam UndangUndang Dasar (UUD) 1945 diamanatkan bahwa tujuan nasional, antara lain, memajukan kesejahteraan umum dan mencerdaskan kehidupan bangsa. Selain itu, ditegaskan pula bahwa bumi dan air dan kekayaan alam yang terkandung di dalamnya dikuasai oleh
\end{abstract}


negara dan dipergunakan sebesar-besar untuk kemakmuran rakyat. Untuk itu, upaya memanfaatkan, mengembangkan, dan menguasai ilmu pengetahuan dan teknologi (iptek) diarahkan agar senantiasa meningkatkan kecerdasan manusia, meningkatkan pertambahan nilai barang dan jasa, serta meningkatkan kesejahteraan masyarakat melalui percepatan industrialisasi sebagai bagian dari pembangunan yang berkelanjutan dengan mengindahkan kondisi lingkungan dan kondisi sosial masyarakat.

Matematika dan sains (MIPA) memiliki peran yang penting dalam menyiapkan anak (sumber daya manusia) memasuki dunia kehidupannya. MIPA pada hakekatnya merupakan sebuah produk dan proses. Produk dari MIPA meliputi fakta, konsep, prinsip, teori, dan hukum. Sedangkan proses pada MIPA meliputi metode atau cara-cara memperoleh, mengembangkan, dan menerpakan pengetahuan yang mencakup cara kerja, cara berpikir, cara memecahkan masalah, dan cara bersikap. Berdasarkan tahapan pada proses ini, Matematika dan Sains memiliki sudut pandang yang berbeda. Matematika dilandasi oleh pola pikir yang deduktif, yaitu dari konsep yang bersifat umum menjadi konsep atau teori yang bersifat khusus. Namun, untuk beberapa kasus, matematika juga menerapkan pola pikir induksif, yang dikenal dengan prinsip induksi matematika. Sedangkan sains dilandasi oleh pola pikir induktif, yang dimulai dengan eksperimen yang bersifat khusus untuk menyimpulkan sebuah konsep yang bersifat umum.

Berdasarkan kurikulum pendidikan nasional, pembelajaran MIPA dan matematika khususnya dimaksudkan agar siswa memperoleh kompetensi ilmu pengetahuan dan teknologi serta kemampuan berpikir ilmiah secara kritis, kreatif dan mandiri. Oleh karenanya, melalui pembelajaran matematika, siswa diharapkan mampu mengembangkan kemampuan berkomunikasi dengan menggunakan bilangan dan simbol-simbol dengan baik. Melalui alur berpikir logis, disertai dengan kemampuan pemecahan masalah yang baik, didukung dengan kemampuan berkomunikasi dan sikap menghargai kegunaan matematika dalam kehidupan, maka diharapkan tujuan pembelajaran matematika, khususnya di jenjang pendidikan dasar dan menengah dapat tercapai. Peraturan Menteri Pendidikan Nasional Nomor 22 Tahun 2006 tentang standar isi, menyebutkan bahwa tujuan mata pelajaran matematika antara lain agar peserta didik memiliki kemampuan untuk memahami konsep matematika, menggunakan penalaran, memecahkan masalah, kemudian mengkomunikasikan gagasan dengan baik, serta memiliki sikap menghargai kegunaan matematika dalam kehidupan sehari-hari (Menteri Pendidikan Nasional, 2006).

Sejalan dengan National Council of Teacher Matematics, NCTM (Hadi dan Radiyatul, 2014; Sumartini, 2016; Van de Walle, 2010, p. 5) yang menetapkan bahwa salah satu keterampilan proses yang harus dimiliki siswa adalah pemecahan masalah matematis (mathematical problem solving). Melalui keterampilan dan kemampuan pemecahan masalah ini, diharapkan siswa mampu mengembangkan keterampilan atau kemampuan pemecahaan masalah untuk menyelelesaikan permasalahan nyata dalam kehidupan sehari-hari (Aisyah, 2007; Muchlis, 2012). Oleh karenanya, penerapan pendekatan pemecahan masalah (problem solving) dalam pembelajaran matematika diharapkan mampu memberikan motivasi kepada siswa untuk mempelajari matematika dan memahami pelajaran matematika secara lebih mendalam.

Pelajar (siswa SD - SMA) merupakan segmen terbesar dalam konteks manusia pembelajar. Pada segmen ini diletakan konsep dasar, rasionalisasi konsep, dan penerapan konsep dasar. Oleh karenanya, jika segmen ini ditangani dengan baik dan serius maka kualitas pelajar khususnya bidang matematika juga 
akan baik dan siap menghadapi kemajuan teknologi dan perkembangan jaman. SMA Negeri 1 Praya merupakan salah satu sekolah menengah yang berada di wilayah Kabupaten Lombok Tengah, Provinsi Nusa Tenggara Barat. Berdasarkan hasil akreditasi sekolah menengah, SMA Negeri 1 Praya merupakan salah satu sekolah unggulan yang berada di Lombok Tengah. Kelompok Bidang IImu Matematika Terapan Program Studi Matematika FMIPA Universitas Mataram melalui kegiatan pengabdian kepada masyarakat ini mengharapkan siswa SMA Negeri 1 Praya Lombok Tengah mampu mengembangkan dan menerapkan keterampilan dan atau kemampuan pemecahaan masalah dalam pembelajaran matematika khususnya dan menyelelesaikan permasalahan nyata dalam kehidupan sehari-hari pada umumnya.

\section{METODE KEGIATAN}

Pengabdian kepada masyarakat ini dilakukan oleh Kelompok Bidang Ilmu Matematika Terapan FMIPA Universitas Mataram pada kelompok siswa sekolah menengah tepatnya di SMA Negeri 1 Praya Lombok Tengah yang dilaksanakan pada tanggal 1 Agustus 2019. Kegiatan pengabdian dilakukan dengan menggunakan metode ceramah interaktif yang dikombinasikan dengan metode diskusi. Paradigma problem solving yang dimaksud adalah strategi pemecahan masalah yang berbasis strategi problem solving yang dikemukakan oleh Polya.

Melalui ceramah interaktif, strategi problem solving model Polya (Polya dan Conway, 2004) dijelaskan dan diterapkan pada beberapa kasus sederhana untuk memudahkan siswa memahami pola dan cara kerjanya dalam menyelesaikan soal matematika. Selanjutnya, penguatan dan pemantapan penerapan tehnik problem solving dalam penyelesaian soal matematika dilakukan melalui metode diskusi terbimbing.

\section{HASIL DAN PEMBAHASAN}

Kondisi Umum Obyek Pengabdian

Obyek pengabdian masyarakat ini adalah perwakilan siswa SMA Negeri 1 Praya kelas XII yang terdiri 80 siswa. Berdasarkan nilai Ujian Nasional (UN) tingkat SLTP Mata Pelajaran Matematika, sebaran obyek pengabdian diberikan oleh Tabel 1.

Tabel 1 Sebaran Obyek Pengabdian berdasarkan nilai UN Mata Pelajaran Matematika tingkat SLTP.

\begin{tabular}{ccc}
\hline No & Interval Nilai & Frekuensi \\
\hline 1 & $X>80$ & 55,95 \\
2 & $71 \leq X \leq 80$ & 38,98 \\
3 & $61 \leq X \leq 70$ & 3,39 \\
4 & $X \leq 60$ & 1,69 \\
\hline
\end{tabular}

Tabel 1 memperlihatkan bahwa sebaran siswa yang menjadi obyek pengabdian memiliki nilai matematika (UN SLTP) lebih dari 70 sebanyak 94,91\% dan yang kurang atau sama dengan 70 hanya sekitar $5,08 \%$. Berdasarkan hasil ini, dapat dikatakan bahwa siswa yang menjadi obyek pengabdian ini memiliki kemampuan matematika yang baik dan bahkan lebih dari separoh jumlah peserta pengabdian memiliki kemampuan matematika sangat baik (55,95\%).

Tabel 2. Persepsi siswa tentang pembelajaran matematika di SMA 1 Praya

\begin{tabular}{|c|c|c|c|}
\hline \multirow[t]{2}{*}{ NO } & \multirow[t]{2}{*}{ INDIKATOR } & JAWABAN & $\begin{array}{l}\text { BAN } \\
\text { EN (\%) }\end{array}$ \\
\hline & & YA & TIDAK \\
\hline 1 & $\begin{array}{l}\text { Apakah pembelajaran } \\
\text { matematika } \\
\text { menyenangkan }\end{array}$ & 72,88 & 27,12 \\
\hline 2 & $\begin{array}{l}\text { Apakah matematika } \\
\text { dibutuhkan dalam } \\
\text { kehidupan sehari-hari }\end{array}$ & 96,61 & 3,39 \\
\hline 3 & $\begin{array}{l}\text { Apakah siswa } \\
\text { mengalami kesulitan } \\
\text { dalam pembelajaran } \\
\text { matematika }\end{array}$ & 91,53 & 8,47 \\
\hline
\end{tabular}


4 Sumber hambatan

dalam pembelajaran

matematika:

Metode pebelajaran

25,42

yang digunakan

Faktor internal siswa

49,15

(malas, kurang

motivasi dII)

Tingkat kesulitan

20,34

materi pelajaran

Pengajar/Guru

1,69

Ketersediaan sumber

belajar

Ketersediaan fasilitas

0

belajar

Lainnya

3,39

Persepsi siswa tentang pembelajaran matematika di SMA Negeri 1 Praya, khususnya siswa yang menjadi obyek pengabdian, terhadap beberapa pertanyaan terkait proses pembelajaran matematika, tingkat kesulitan, hambatan dan daya dukungnya diberikan oleh Tabel 2. Berdasarkan Tabel 2 pertanyaan ke-3, terlihat ketidakkonsistenan jawaban responden dengan jawaban pertanyaan ke-1 dan hasil Tabel 1. Ketidakkonsistenan ini terurai pada jawaban pertanyaan ke-4. Terlihat bahwa hambatan terbesar dalam pembelajaran matematika berasal dari faktor internal siswa yaitu sebesar 49,15\%. Selanjutnya secara berturut-turut hambatan dalam pembelajaran matematika berasal dari metode pembelajaran yang dipilih oleh guru (25,42\%), tingkat kesulitan materi pelajaran (20,34\%), faktor pengajar/guru sebanyak $1,69 \%$ dan faktor lainnya sebanyak 3,39\%.

\section{Paradigma Problem Solving sebagai Solusi Pembelajaran Matematika Sekolah}

Pembelajaran problem solving merupakan bagian dari pembelajaran berbasis masalah (Problem Based Learning, PBL). Menurut Arends (2008: 45) pembelajaran berdasarkan masalah merupakan suatu pendekatan pembelajaran yang menempatkan siswa pada posisi mengerjakan permasalahan yang otentik dengan maksud untuk menyusun pengetahuan mereka sendiri. Pada pembelajaran berbasis masalah siswa dituntut untuk melakukan pemecahan masalahmasalah yang disajikan dengan cara menggali informasi sebanyak-banyaknya, kemudian dianalisis dan dicari solusi dari permasalahan yang ada.

Terhadap konteks cara atau metode pemecahan masalah sendiri, dalam penerapannya metode ini bersifat fleksibel dalam arti cara atau metode yang digunakan tidak tunggal, tergantung cara berpikir dan pengalaman siswa itu sendiri. Terhadap cara berpikir (secara matematis) ini, siswa harus dapat mengemukakan ide-ide matematikanya dalam berbagai cara. Sejalan dengan hal ini, NCTM-National Council of Teacher Matematics (Hadi dan Radiyatul, 2014; Sumartini, 2016; Van de Walle, 2010, p. 5) merumuskan ada lima keterampilan proses yang harus dimiliki siswa dalam berpikir matematis, yaitu: (1) pemecahan masalah matematis (mathematical problem solving); (2) penalaran dan pembuktian matematis (mathematical reasoning and proof); (3) komunikasi matematis (mathematical communication); (4) koneksi matematis (mathematical connection); penyajian/representasi matematis (mathematical representation).

Pemerintah Indonesia mengakomodasi proses berpikir ini yang dirumuskan oleh NCTM ini dengan menempatkan kata pemecahan masalah pada setiap kompetensi dasar yang akan dicapai di sekolah menengah. Pengakomodasian ini mempunyai harapan agar siswa melalui pembiasaan menghadirkan pola pikir dan proses pemecahan masalah, diharapkan mampu mengembangkan keterampilan atau kemampuan pemecahan masalah yang sering dijumpai dalam kehidupan sehari-hari (Aisyah, 2007; dan Muchlis, 2012). 
Pemecahan masalah pada dasarnya merupakan suatu proses yang ditempuh oleh seseorang untuk menyelesaikan masalah yang dihadapi hingga masalah tersebut tidak lagi menjadi masalah baginya. Untuk menyelesaikan atau memecahkan suatu masalah matematika, diperlukan strategi pemecahan masalah yang kemudian diintegrasikan dalam langkah-langkah pemecahan masalah matematika. Pada tulisan ini, model yang dijadikan dasar untuk proses pemecahan masalah matematika pada materi statistika, merujuk pada model yang diusulkan oleh Pólya and Conway (2004) dalam bukunya berjudul "How to Solve It", yang terdiri atas beberapa tahapan yaitu (1) memahami masalah; (2) menyusun rencana untuk menyelesaikan masalah; (3) melaksanakan rencana yang dibuat pada langkah kedua; (4) memeriksa ulang proses dan jawaban yang diperoleh.

1) Memahami masalah (understanding the problem), merupakan langkah awal dalam proses pemecahan masalah ini. Dalam hal ini siswa diminta untuk memahami masalah atau soal yang akan diselesaikan. Untuk memahami masalah yang diberikan, beberapa hal atau pertanyaan yang perlu dipahami dalam langkah pertama ini, yaitu: (i) apakah setiap kata pada permasalahan dapat dimengerti?, (ii) bisakah menyatakan kembali masalah dengan menggunakan kata-kata anda sendiri?, (iii) apakah informasi yang ada cukup (data mengenai syarat perlu dan cukup tersedia)?, dan (iv) jika memungkinkan buat ilustrasi yang menggambarkan hubungan antara data-data yang ada.

2) Menyusun rencana (device a plan) untuk menyelesaikan masalah. Pada tahapan ini beberapa hal yang perlu diperhatikan adalah terkait dengan pertanyaan atau pernyataan (i) variabel apa saja yang diberikan atau diketahui dan hal apa yang dipertanyakan, (ii) teorema atau hukum apa saja yang berkaitan dengan permasalahan yang diberikan? (iii) pernahkah ada masalah yang serupa dan telah diselesaikan? (iv) dapatkan cara serupa diterapkan pada masalah yang dihadapi?

Dalam merencanakan langkah kedua ini, beberapa metode yang dapat pertimbangkan antara lain:

a) Menebak dan menguji (guess and check)

b) Menggunakan variabel (use a variable)

c) Membuat ilustrasi atau diagram (draw a picture or diagram)

d) Melihat pola (look for a pattern)

e) Selesaikan masalah yang sederhana (solve a simpler problem)

f) Gunakan penalaran langsung atau tidak langsung (use direct or indirect reasoning)

g) Menggunakan langkah mundur (work backward)

h) Menyelesaikan suatu persamaan (solve an equation)

i) Menggunakan suatu rumus tertentu (look for a formula)

3) Melaksanakan rencana yang dibuat (carry out the plan). Pada tahapan ini langkah yang dilakukan adalah melaksanakan salah satu rencana pada tahapan kedua. Yang perlu menjadi perhatian pada saat menerapkan langkah ini adalah (i) apakah setiap langkah yang ditulis sudah benar? dan apakah dapat dibuktikan kebenarannya?

4) Memeriksa ulang proses dan jawaban yang diperoleh (looking back). Pada tahapan ini, langkah yang dilakukan adalah memeriksa kembali setiap langkah yang telah ditulis baik berupa angka, simbol/notasi, maupun pernyataan penghubungnya. Ada beberapa hal yang perlu diperhatikan pada langkah ini, yaitu:

a. Apakah solusi yang ditulis sudah benar? 
b. Apakah solusi sudah menjawab permasalahan dengan jelas?

c. Adakah alternatif solusi yang lebih mudah?

d. Dapatkah solusi diperumum untuk kasus yang lebih luas?

Satrianawati (2015) menyimpulkan bahwa penerapan empat langkah metode problem solving yang dikemukan oleh Polya dalam pembelajaran matematika mampu membentuk karakter siswa untuk berpikir logis, kritis, konsisten, pencari kebenaran, dan berhati-hati dalam setiap tindakan dan perbuatan terutama saat memutuskan sesuatu atau mengambil kesimpulan.

Tabel 3. Persepsi siswa terkait evaluasi yang menggunakan soal cerita dalam pembelajaran matematika

\begin{tabular}{|c|c|}
\hline \multicolumn{2}{|c|}{ Persepsi Terkait Soal Cerita (dalam \%) } \\
\hline Dianggap sulit & 23.53 \\
\hline \multicolumn{2}{|l|}{ Jawabannya sulit dan } \\
\hline panjang & 2.94 \\
\hline \multicolumn{2}{|l|}{ Mencari tahu } \\
\hline informasi yang ada & 17.65 \\
\hline \multicolumn{2}{|l|}{ Tergantung tipe } \\
\hline materinya & 8.82 \\
\hline \multicolumn{2}{|l|}{ Membuat lebih } \\
\hline pusing & 2.94 \\
\hline \multicolumn{2}{|l|}{ Rumus apa yang } \\
\hline harus digunakan & 23.53 \\
\hline \multicolumn{2}{|l|}{ Bingung, tidak } \\
\hline memahami soal & 2.94 \\
\hline \multicolumn{2}{|l|}{ Menjebak, soal } \\
\hline \multicolumn{2}{|l|}{ panjang jawabannya } \\
\hline pendek & 5.88 \\
\hline \multicolumn{2}{|l|}{ Soalnya membuat } \\
\hline bingung (tidak rutin) & 11.76 \\
\hline
\end{tabular}


menunggu bantuan dari guru atau temannya dan sebanyak 26,67 \% yang berusaha untuk membuat ilustrasi berdasarkan informasi yang diberikan dalam soal.

Tabel 5. Banyak siswa yang menjawab permasalahan dan validitasnya

\begin{tabular}{|c|c|c|}
\hline $\begin{array}{c}\text { Penyelesaian } \\
\text { Masalah }\end{array}$ & $\begin{array}{c}\text { Menjawab } \\
\text { Soal (\%) }\end{array}$ & $\begin{array}{c}\text { Validitas } \\
\text { Jawaban (\%) }\end{array}$ \\
\hline Praktis & Tidak & Benar Salah \\
\hline
\end{tabular}

Permasalahan

yang rutin $\quad 87,50 \quad 12,50 \quad 100 \quad 0$

Permasalahan

$\begin{array}{lllll}\text { yang tidak rutin } & 56,26 & 43,75 & 0 & 100\end{array}$

Untuk menguji kemampuan siswa dalam

penerapan strategi problem solving Polya, siswa diberikan dua tipe permasalahan matematika yang terdiri atas dua tipe, yaitu soal rutin dan soal cerita. Jawaban siswa terhadap dua permassalahan tersebut diberikan oleh Tabel 5. Terhadap tipe soal yang rutin, $87,50 \%$ siswa yang menjawab soal ini memiliki jawaban yang benar (100\%), hanya 12,50 $\%$ siswa yang tidak menjawab soal ini. Sedangkan untuk soal cerita, hanya 56,26 \% siswa yang menjawabnya dan dari kesemua siswa yang menjawab tersebut tidak ada seorang pun yang memiliki jawaban yang benar.

Tabel 5 mengkonfirmasi jawaban siswa pada Tabel 3 yaitu sebesar $23,53 \%$ siswa menganggap soal cerita (tidak rutin) sesuatu yang sulit, dan sebanyak 91,53 \% siswa mengalami kesulitan dalam pembelajaran matematika (Tabel 2), serta sebanyak 49,15 \% siswa kurang termotivasi dalam belajar, terutama untuk hal yang baru dan dianggap sulit (Tabel 2).

Pembelajaran dengan pendekatan problem solving memiliki keunggulan dan kelemahan. Adapun keunggulan model pembelajaran problem solving diantaranya melatih siswa untuk merencanakan suatu penemuan, berpikir dan bertindak kreatif, memecahkan masalah yang di hadapi secara realistis, mengidentifikasi dan melakukan penyelidikan, menafsirkan dan mengevaluasi hasil pengamatan, merangsang perkembangan kemajuan berpikir siswa untuk menyelesaikan masalah yang dihadapi dengan tepat, serta dapat membuat pendidikan sekolah lebih relevan dengan kehidupan nyata. Sedangkan kelemahan pendekatan pembelajaran problem solving diantaranya memerlukan alokasi waktu yang lebih panjang dibandingkan dengan metode pembelajaran yang lain.

\section{KESIMPULAN DAN SARAN}

\section{Kesimpulan}

Pada pembelajaran matematika, metode problem solving merupakan salah satu metode yang berbasis masalah. Pada kegiatan pengabdian ini, prosedur dan strategi pemecahan masalah berbasis Model Polya diberikan dan kemudian diakhir kegiatan diberikan tes untuk mengukur pemahaman dan kemampuan siswa dalam menerapkan prosedur dan strategi pemecahan masalah berbasis Model Polya. Berdasarkan hasil tes, siswa SMA Negeri 1 Praya Lombok Tengah yang menjadi obyek kegiatan pengabdian belum familiar atau biasa menerapkan metode problem solving (Model Polya) dalam menyelesaikan permasalahan matematika. Berdasarkan tipe soal yang diujikan, terlihat bahwa siswa SMA Negeri 1 Praya belum memiliki pemahaman dan kemampuan problem solving yang baik, khususnya dalam menyelesaikan tipe soal yang tidak rutin (soal cerita).

\section{Saran}

Berdasarkan hasil kegiatan pengabdian kepada masyarakat ini, agar keunggulan metode problem solving dapat dioptimalkan pelaksanaannya di SMA 1 Praya Kabupaten Lombok Tengah perlu dilakukan secara integral oleh guru bidang studi, 
khususnya guru bidang studi matematika. Dalam hal ini, agar pembelajaran matematika berbasis metode problem solving berhasil perlu dilakukan beberapa hal antara lain (i) menyiapkan kelas, kalau bisa kelas tidak terlalu besar sehingga proses pendampingan bisa dilakukan secara optimal; (ii) sebelum pembelajaran dilakukan, guru sedapat mungkin membuat ringkasan (summary) terkait materi yang akan dibelajarkan; (iii) dalam proses pembelajaran, khususnya untuk tahap awal penerapan metode problem solving, guru perlu memberikan stimulasi dan arahan yang terkait dengan strategi atau langkah pemecahan masalahnya; (iv) untuk menuntaskan pemahaman siswa terkait materi yang diajarkan, guru perlu mendiskusikan secara klasikal terhadap satu atau dua soal yang menjadi permasalahan, dan (v) secara klasikal, guru dan siswa membuat kesimpulan terhadap materi yang dibelajarkan.

\section{UCAPAN TERIMA KASIH}

Kegiatan pengabdian kepada masyarakat ini didanai menggunakan dana DIPA BLU Universitas Mataram Tahun Anggaran 2019/2020. Oleh karenanya, kami menyampaikan terima kasih kepada Rektor Universitas Mataram, dan khususnya kepada Dekan FMIPA. Ucapan terima kasih juga kami sampaikan kepada segenap pimpinan SMA Negeri 1 Praya Kabupaten Lombok Tengah yang telah menyiapkan sarana dan prasarana untuk terselenggaranya kegiatan pengabdian ini.

\section{DAFTAR PUSTAKA}

Aisyah, N., 2007. Pengembangan Pembelajaran Matematika SD. Direktorat Jenderal Pendidikan Tinggi Departemen Pendidikan Nasional: Jakarta.

Arends, Richard I., 2008. Learning to Teach-Belajar untuk Mengajar, Edisi Ketujuh, Buku Dua, Terjemahan Helly Pajitno Soetjipto dan Sri
Mulyantini Soetjipto. Pustaka Pelajar: Yogyakarta.

Muchlis, E. E., 2012. Pengaruh Pendekatan Pendidikan Matematika Realistik Indonesia (PMRI) Terhadap Perkembangan Kemampuan Pemecahan Masalah Siswa Kelas II SD Kartika 1.10 Padang, EXACTA, 10(2), hal. 136-139.

Pólya, G. and Conway, J. H., 2004. How to Solve It: A New Aspect of Mathematical Method. Princeton University Press: New Jersey.

Hadi, S., dan Radiyatul, R., 2014. Metode Pemecahan Masalah Menurut Polya Untuk Mengembangkan Kemampuan Siswa dalam Pemecahan Masalah Matematis di Sekolah Menengah Pertama, EDU-MAT, 2(1), Retrieved from http://ppip.unlam.ac.id/journal/ index.php/edumat/article/view/603.

Satrianawati, 2015. Metode Problem Solving dalam Pembelajaran Matematika sebagai Bagian Dari Pembentukan Karakter, Prosiding Seminar Nasional Matematika dan Pendidikan Matematika UNY, ISBN. 978-60273403-0-5.

Sumartini, T. S., 2016. Peningkatan Kemampuan Pemecahan Masalah Matematis Siswa Melalui Pembelajaran Berbasis Masalah, Mosharafa: Jurnal Pendidikan Matematika, 5(2), hal. 148-158.

The National Council of Teacher of Mathematics, Inc., 2000. Principles and Standards for School Mathematics, Association Drive, Reston, VA: Library of Congres Cataloguingin-Publication Data.

Van de Walle, J. A., 2010. Elementary and Middle School Mathematics: Teaching Developmentally, Pearson /Allyn and Bacon: Boston. 